\title{
When foresters reterritorialize the periphery: post-socialist forest politics in Białowieża, Poland
}

\author{
Eunice Blavascunas ${ }^{1}$ \\ Whitman College, USA
}

\begin{abstract}
State Forestry is regarded by political ecologists as a coercive tool deployed by state authorities to nationalize, control and order the forest as a resource within the territory of a nation. The consequence of this is civilizing local people and subjecting them to the grip of the state. Much of this literature comes from the global South. However, in the iconic Białowieża Forest in eastern Poland, touted as Europe's last primeval forest for its old oaks and woodland bison, state foresters altered the prominence of their nationalistic and nationalizing history in three surprising ways: 1) they downplayed their historical role in nationalizing the periphery in the 1920s when the area was split between a national park and a forest belonging to the newly formed Polish state (the Second Polish Republic); 2) they created new allegiances with the Belarusian-identified local population, and 3) they referenced neighbouring Belarus' preferential management of forests within the adjacent Belovezshkaya National Park. This article weaves together insights from political ecology, post-socialist studies and environmental history in an ethnographic account of Polish state foresters in interaction with biologists, conservationists and "local" people in the fight to expand the Polish Białowieża National Park from 1990-2013. Foresters downplayed the forest's significance for the nation, at least rhetorically, because conservationists viewed and promoted the forest as having national, European and global heritage. Yet the globalized cosmopolitics of conservationists enabled, or perhaps even forced, foresters to frame their concerns in a language of local and ethnic minority rights and community participation. The transcendence of ethnic and cultural differences by foresters over nearly ninety years of existence marks an important and novel component of the post-socialist period.
\end{abstract}

Keywords: Post-socialist, political ecology, forests, environmental history, Poland, Belarus, foresters, ethnography, periphery

\begin{abstract}
Résumé
La foresterie domaniale est considérée par les «political ecologists» comme un outil coercitif déployés par les autorités de l'État de nationaliser, de contrôler et d'ordonner la forêt sur le territoire d'une nation. La conséquence de contrôle par l'État est la civilisation des populations locales et en les soumettant à la poignée de l'État. Une grande partie de cette littérature vient du Sud. Toutefois, dans la forêt de Białowieża dans l'est de la Pologne, présentée comme dernière forêt primitive d'Europe pour ses vieux chênes et les bisons des bois, les forestiers de l'État modifier l'importance de leur histoire nationalistes et la nationalisation de trois façons surprenantes: 1) il a minimisé leurs actions passées dans les années 1920s, lorsque la zone a été divisée entre un parc national et une forêt appartenant à la nouvelle Deuxième République de Pologne; 2) ils ont créé de nouvelles allégeances avec la population locale du Bélarus, et 3) ils ont regardé à travers la frontière pour comprendre la gestion des forêts de Biélorussie et leurs parcs. Cet article tisse idées de l'écologie politique, les études post-socialistes et de l'histoire de l'environnement dans la lutte pour élargir le parc national polonais Białowieża 1990-2013. Les forestiers ont reconnu la valeur de la conservation internationale de la forêt, et pas seulement sa valeur économique. Ils ont soutenu les droits des minorités locales et ethniques et la participation communautaire. La transcendance des différences ethniques et culturelles par les forestiers sur près de 90 années d'existence marque un élément important et nouveau de la période post-socialiste.
\end{abstract}

Mots-clés: post-socialistes, l'écologie politique, les forêts, l'histoire de l'environnement, la Pologne, la Biélorussie, les forestiers, l'ethnographie, la périphérie

\footnotetext{
${ }^{1}$ Dr. Eunice Blavascunas, Assistant Professor of Anthropology and Environmental Studies, Whitman College, 345 Boyer Ave., Walla Walla, WA 99362, USA. Email: Eunice.Blavascunas "at"gmail.com. Thankyou to the Rachel Carson Center, Germany for providing me with the time and space to complete this article, and two reviewers. Research was supported by the Switzer Foundation, the National Council of East European and Eurasian Research, the Fulbright Foundation, and the Kosciuszko Foundation. I especially appreciate the time and resources of Lasy Panstwowe (Polish State Forestry), The Polish Academy of Science's Mammal Research Institute (IBS), The Institute for Forestry Research (IBL), village inhabitants of Białowieża, Teremiski, Budy, Narewka, Masiewo and Podolany, and the Uniwersytet Powszeczny in Teremiski for providing me with long term housing. The map for this article was produced by Marcin Gorny.
} 


\section{Resumen}

Los parques forestales estatales son considerados por los especialistas en política ecológica como una herramienta coercitiva implementada por las autoridades estatales para nacionalizar, controlar y ordenar la masa forestal como recurso dentro de un territorio o una nación. La consecuencia de esto es civilizar a la población local y someterla al control del estado. Gran parte de la literatura al respecto proviene del Sur global. Sin embargo, en el icónico bosque Białowieża en el este de Polonia, considerado como el último bosque primitivo por sus viejos robles y sus bisontes europeos los silvicultores estatales alteraron la prominencia de su historia nacionalista y nacionalizadora de tres maneras sorprendentes: 1) minimizaron su papel histórico al nacionalizar la periferia en la década de 1920 cuando el área se dividió entre un parque nacional y un bosque perteneciente al estado polaco recién formado (la Segunda República polaca); 2) crearon nuevas alianzas con la población local que se identificaba como bielorrusa, y 3) la relacionaron con la gestión preferencial de los bosques de la vecina Bielorrusia en el Parque Nacional adyacente Belovezshkaya. En este artículo se entrelazan puntos de vista de la ecología política, estudios sobre el postsocialismo e historia del medio ambiente en un informe etnográfico de los silvicultores estatales polacos en la interacción con los biólogos, conservacionistas y personas "locales" en la lucha para ampliar el Parque Nacional de Białowieża polaco entre 1990 y 2013. Los silvicultores minimizaron la importancia del bosque para la nación, al menos retóricamente, porque los conservacionistas percibieron y promovieron el bosque como patrimonio nacional, europeo y mundial. Sin embargo, la cosmopolítica globalizada de los conservacionistas permitió, o tal vez incluso forzó a los silvicultores a enmarcar sus inquietudes en un lenguaje de derechos de las minorías étnicas y locales y la participación comunitaria. La trascendencia de las diferencias étnicas y culturales por los silvicultores durante casi noventa años de existencia marca un componente importante y novedoso del período post-socialista.

Palabras clave: postsocialista, ecología política, los bosques, la historia ambiental, Polonia, Bielorrusia, los forestales, la etnografía, la periferia

\section{Introduction}

State Forestry is frequently regarded by political ecologists, most working on cases in the global South, as a coercive tool deployed by state authorities to nationalize, control and order the forest as a territorial resource for the nation. Local people are civilized and subjected to the grip of the state. However, in the iconic Białowieża Forest in eastern Poland (Figure 1), touted as Europe's last primeval forest for its old oaks and woodland bison, state foresters pursued a different path. After the collapse of Polish communism in 1989, they downplayed the forest's significance for the nation, at least rhetorically. By contrast, conservationists argued the forest has national, European and global heritage. This enabled, or perhaps even forced, foresters still committed to forest 'management' and some logging to frame their concerns as protecting local and ethnic minority rights and community participation. The setting aside of ethnic and cultural differences by foresters in this region over nearly ninety years marks an important and novel component of the post-socialist period. It is one that has rarely been studied in political ecology, especially in regards to forests. This article makes a critical empirical intervention into this small but growing body of literature on the post-socialist political ecology of forests (Cellarius 2004; Staddon 2009; Stahl 2010).

Poland's Białowieża Forest became a symbolic icon of Europe's primeval nature in the years following the political and economic changes of 1989. Polish conservationists seized opportunities triggered by the changes to draw attention to the threatened remaining old growth within the forest, eightythree percent (47,500 ha) of which is commercially logged and only seventeen percent of which is a national park (10,500 ha), in which half is strictly protected. The image of the forest propagated at the international and national level was of a pristine landscape of towering old trees, including standing dead trees and woody debris on the forest floor; in other words, what one could see in the strictly protected part of the national park. This image concealed the much larger logged forest, and this was not visible in the evocative international messages. Foreign visitors often had no idea that it was only a small national park that was truly protected. Locals, however, were aware that a large part of the transboundary forest stretching into neighboring Belarus had been logged and replanted by resident woodcutters under the direction of State Forestry for nearly a century. 
Polish foresters working for the state had pursued nationalist causes when they formed their organization in the 1920s. But after 1989 they defended local rights reactively, and sometimes against national interests. By the 2000s they even supported in a populist fashion the interests of the local Belarusian minority. As the forest became more symbolic of pristine threatened nature at the national and international scale, foresters used the opportunity to de-emphasize their nationalist past and to unify the locals into a multi-cultural set of political actors who could challenge forest protection in an expanded national park.

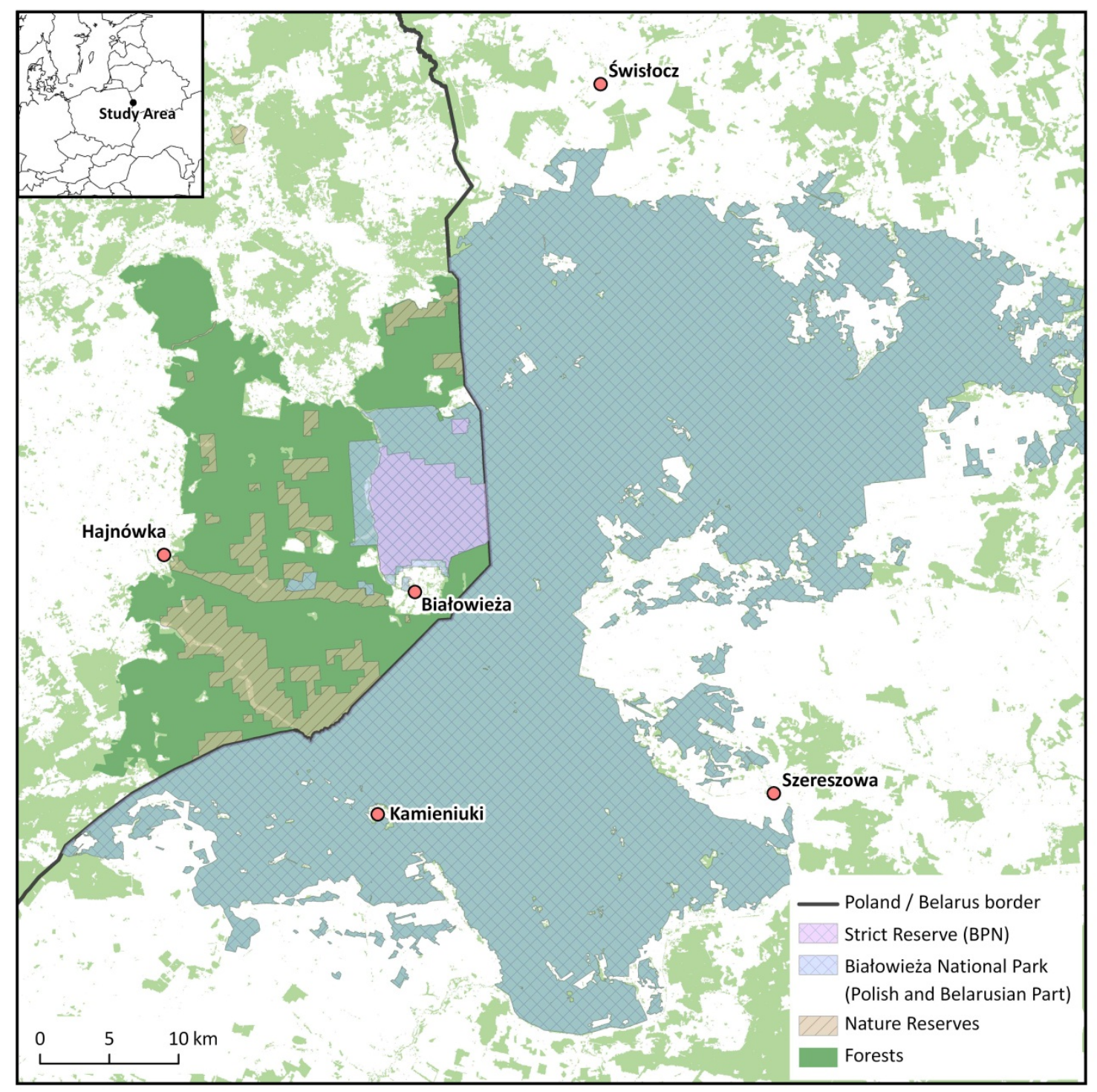

Figure 1: The Białowieża forest and National Park in regional context.

\section{Methods and structure}

I conducted research for this article from 1998-2014 in masters, doctoral and postdoctoral research. My methods included ethnography, living in the villages of the Białowieża Forest region, working in biological and forestry research institutes, attending official meetings, taking extensive daily notes based on my experiences and observation, semi-structured interviews with more than fifty people, archival research 
at the Białowieża National Park and Forestry Research Institute in Białowieża, and textual analysis of online materials.

In this paper I locate my research in political ecology debates about foresters. I illustrate why literature about post-socialism is important for understanding foresters as a nationalizing and globalizing force in the European periphery. In the next section I provide an environmental history of the forest back to the nineteenth century, which explains the post-socialist history between Poles and Belarusians. This sets the stage for ideas about nationalizing the Polish periphery in the early twentieth century. The rest of the article presents ethnographic evidence and analysis of the post-socialist present, focusing heavily on how foresters came to support 'the local.' I conclude with a discussion of how foresters respond to the globalized framing of the forest as threatened by their mismanagement.

\section{Foresters and the order of post-socialist Poland}

According to Arjun Appadurai (2003: 338) "the production of locality... challenges the order and orderliness of the nation state." In the usual portrayal of foresters in the political ecology literature, statebacked foresters colonize the periphery, especially when radical changes to borders or the nation state provide opportunities for new groups to seize control. Foresters civilize locals and subject them to the grip of the state (Peluso 1992; Scott 1998). This model would have neatly described post WWI Poland, but not after 1989. As the uniqueness of the forest is extolled at the national and international level, Białowieża has become a site for international and (urban) Polish tourist consumption. Polish state foresters were able to strategically amplify the importance of the sovereignty of the local, because of the scaling up of the importance of conservation in this region (Franklin 2002; Igoe 2004; Lowe 2006; Peluso 1993). They also responded to global conservation discourses about community management of forests and ecological forestry management (Brosius et al. 2005; Carr and Halvorsen 2001; Hackel, 1999; Menzies 2007; Tsing and Zerner 2000). The Białowieża case offers an important opportunity to question many assumptions about the concepts of periphery, the local, and the specific set of historical circumstances in post-socialist Europe used to evaluate control of natural resources (Cellarius 2004; Schwarz 2006).

I show how opposing parties have used different globalized conservation discourses, rather than examining the production of locality through tourist practices or through landscape attachments to regional distinctiveness and cultural heritage. Juggling these has enabled foresters to challenge antipathy to local Belarusian interests and its forest management. ${ }^{2}$ There is something distinctly post-socialist about this move, because the breakup of socialist states takes shape in paradoxes, ambiguities, contradictions and even nostalgia (Berdhal 2010; Hahn 2007; Dunn 2004; Yurchak 2005). Polish foresters in Białowieża successfully married their resource management goals with the minority Belarusian and multi-ethnic agendas that emerged from the socialist era, which were only possible because Belarus still exists as a one party political state. The post-socialist specifics of this case emerge in how actors conjure and imagine the local, the nation and foresters' representation of the state some two decades after the first free elections in Poland.

While clearly part of continental Europe, post-socialist Europe is seen as its historically underdeveloped and peripheral component, an 'almost' or 'not quite' 'west', where the term 'peasant' still has deep cultural meaning (Leonard and Kaneff 2002). As Larry Wolfe (1994) points out 'eastern Europe' is an invention of 'western Europe', setting up a teleological and yet neve-obtainable goal, seen from the perspective of the eastern European invention of western Europe (Boym 2001). This in the context of a very fast transition in Poland from near subsistence agriculture in the 1990s to participating in globalized agricultural markets, and in the case of Białowieża, globalized tourist markets and ecological finance. ${ }^{3}$

\footnotetext{
${ }^{2}$ Belarus is often portrayed as draconian and anti-western (non-democratic) in Polish and international discourse. Its President, Alexander Lukashenko, abolished his own term limits and has ruled the country since 1994.

${ }^{3}$ Globalized timber markets, while also an important point of analysis, are not within the scope of this study. According to the reports of forestry officials, wood was processed within a two hundred mile radius by Polish companies and used within Poland.
} 


\section{Periphery}

A primeval forest's 'survival' in eastern Poland symbolizes a deep historic link for Europeans. Over the course of several centuries empires and settlers cleared the mixed hardwood forests that once spanned medieval Europe (Vera 2000). ${ }^{4}$ Białowieża is a wet lowland complex of fen, forest and meadow. Scholarship on protected areas and 'pristine' nature has taught us that it is precisely the existence of the 'modern' that conjures up pre-history (Anderson and Grove 1987; Beinart and Coates 1995; Braun 2002; Crandell 1993; MacKenzie 1990; Neumann 1998; Ranger 1999). Robert Pogue Harrison (1992) proposes that the concept of civilization has created a myth of traumatic separation between Europe and sylvan prehistory. Forests, especially ancient forests, offer a kind of universality so that forest prehistory supports origin stories of the nation. Outbreaks of passion and love for 'timeless nature' occur at moments when the nation is on a rapid path of modernization (Schwartz 2006). Poland sits at such a juncture, as do many formerly socialist nations of East-Central Europe.

The ineffectiveness of environmental protection under Communism is recognized (Gille 2007; Hicks 1996; Manser 1993; Petryna 2002). Forests were destroyed by acid rain, soils were contaminated by heavy metals, polluting industries belched dioxins into the sky, and the Chernobyl nuclear disaster occurred in 1986. These failures of communist modernity (failed in the sense that they didn't 'properly' modernize and they caused health and environmental catastrophes) also had several unintended benefits for nature. Europe's last primeval forest 'survived' in contemporary Poland, at the eastern-most edge of today's European Union.

The forest provided conservationists and Poles more widely with symbolic capital to leverage against their western counterparts' claims that they were not properly modern. Poland, as with many postsocialist, 'underdeveloped' countries that have joined the European Union since 2004, possessed some of the best biodiversity in Europe, and these locations become nation-making tools that consolidated national pride through the international attention they received. Białowieża contained species long extirpated from the rest of Europe, including all nine species of woodpecker, and most symbolically, a free roaming bison population, almost synonymous with the name Białowieża. If Poland could protect this outpost of rare European nature it meant that they had the history, resources and etiquette to think and act at a Europe-wide scale.

A global conservation agenda is generally depicted as benefiting all of humanity (Gezon 2006; Heatherington 2010). Biodiversity protection evokes our evolutionary humanity unconstrained by borders and time (Wilson 2012). Conservationists within Poland, widely linked to European and global conservation groups, want Poland to be perceived as exceptional for preserving Europe's last lowland old growth under difficult historical circumstances, just as Poland has sought to define itself as central to Europe and European democracy (Blavascunas 2008; Davies 2005; Franklin 2002).

Europe's own peripheries, including much of Southern Europe, Scotland, Ireland and Wales, and Eastern Europe developed a different kind of alter ego, and alterity, in regards to Europe and nature (Hechter 1999, Herzfeld 1987). Those alter egos rested not in an 'exotic' other, as with colonial sites of outstanding natural value, but in a familiar other, a Europe 'as it once was.' This secondary category is what keeps people in Białowieża working with and against each other to rid the region of its peripheral status on the one hand, and to turn the survival of rare nature into 'progress' on the other. Survival of something that marks the past points to its retardation in the present (Gellner 1988). That which survives is not really fit to survive, which is what makes something a relic in 'normal' or 'modern' Europe. It is within these two positions that foresters operate: Białowieża as a primeval European relict, and Białowieża as a backwards outpost in need of development and democracy.

The specificity of a different kind of historical experience, an experience irrevocably altered by state socialism in the twentieth century, and the longer period of dividing Eastern Europe between the more and less developed parts of Europe, makes this part of the world an important place for thinking about the frames used for analyzing community knowledge about forests and foresters' control over resources. That

\footnotetext{
${ }^{4}$ Frans Vera proposed the argument that European woodlands were much more of a mosaic of open grazing areas with forest than previously thought (Vera 2000). Vera's theory countered the view of medieval Europe as densely forested.
} 
the state is not a postcolonial state, and that the state seeks its means of legitimacy with and in opposition to Europe and the European Union, means that state agendas are plural and cause conflicts over the very definition of natural European forests.

\section{Forestry and the sovereign local}

When nations apply scientific forestry they commit themselves to visions of progress, in all the universalizing and modernizing sense of that word (Lowood 1990; Rajan 2006; Scott 1998; Sivaramakrishnan 1999; Sivaramakrishnan and Agrawal 2003). Progress often means moving peasants off the land, ceasing communal property, into schemes to improve productivity (Sunseri 2012). Foresters in the global south have a constructed notion of a sovereign local population (Andrews 2002, 2009; Hecht and Cockburn 1990; Peluso 1992; Raffles 2002). The categories peasant and village take on different meanings to those in Europe (Greenough and Tsing 2003; Heatherington 2010; Kingston-Mann 1999; Taussig 1980). The sovereign local has different forest knowledge to the forester or to compliant laborers brought in to replace the long established, but resistant local population (Kosek 2006; Peluso 1992; Scott 1998).

Anna Tsing's convincing argument that local knowledge has always had to come into friction with universal knowledge has marked an important theoretical advance in this debate (Tsing 2004). It can be applied in situations where foresters or conservationists act at different scales to manage resources. Accordingly, on the ground, local knowledge co-produces universal knowledge through a conflictual engagement. In Białowieża local knowledge is frequently constructed as Belarusian, given the ethnic minority that dominates the region, but also as 'village', 'autochthonous' and in opposition to national and international misconceptions by external conservation actors about the forest and the people who live there (Blicharska et.al 2010).

Community empowerment and community managed forests are also globally circulating categories that inflect at the level of local politics in Białowieża. Conservationists generally prefer foresters to become land managers who carry out scientific recommendations for managing the primeval forest. Foresters themselves have courted the guidance of western development experts who offer advice on how commercial forestry and conservation can be compatible. The identity of Belarusians is wrapped up in this debate. They were first excluded from commercial logging operations, but have latterly become a symbol of the 'local' and of local timber harvesting. Nonetheless, an authentic local identity is hard to pin down, since the forest was once in royal ownership, before the different phases of state ownership. Its meaning is also important.

\section{From royal hunting ground to exploited forest}

Royal protection of the Białowieża Forest began in 1409 when King of the Polish Lithuanian Commonwealth, Wladyslaw Jagiello, set off on an eight day hunt to supply game for his retinue at the battle of Grunwald, a historical event coinciding with the Christianization of the last pagan outposts of Europe (Samojlik 2005:9, Weisman 2007). From then on, various elites with some connection to the Polish state (a multi-ethnic unit for much of its existence) continued to use the Forest as an exclusive hunting reserve. Local inhabitants were given titles to their land directly from rulers and expected to guard the forest in return (Karcow 1903:25-45). From the end of the eighteenth century until the outbreak of World War I the rights of the larger Polish landowners were increasingly encroached upon in a Poland partitioned by three larger powers, Prussia, the Austro-Hungarian Empire and Russia.

During these partitions Russians took over large forested estates in eastern Poland where Białowieża lies. In the early nineteenth century it was in vogue for each Pole to showcase the scientific forestry management of these estates (Schama 1995:45-60). Czar Alexander further subdued the landed Polish gentry by shutting down the forestry school in Warsaw, known as a bastion of discontent that supported the Polish national cause in 1832 after a failed Polish insurrection against Czarist Russia. This event retains great resonance even in contemporary Poland (Schama 1995:64). Following the second 
insurrection against Russia in 1863, Catholic Churches were banned from the forest region and the population largely converted to the Russian Orthodox faith. ${ }^{5}$

Beginning in 1915, after six hundred years of royal protection with limited logging, occupying German forces systematically logged the forest for the first time in its history. Over the course of World War I, German military commanders cut 5 million cubic meters of timber from 6,500 hectares. The German foresters considered Białowieża to be a decadent forest in need of use. The raw materials supported the needs of their wartime state (Sunseri 2012: 307).

German forces built networks of narrow gauge railroad lines to transport timber. They set up an infrastructure of twenty-four sawmills and a chemical wood-processing factory in the village of Hajnowka, at the western edge of the forest, which grew to be a booming town (Figure 1). They conscripted four to six thousand workers from nearby villages and brought in prisoners of war (Sunseri 2012: 319). German foresters used arguments they had applied in the hardwood old growth forests of their former West Africa colony, Kamerun (Cameroon). The Urwald model was premised on the idea that old forests needed to be protected from peasants, who would waste their economic potential (Sunseri 2012: 322).

When World War I ended in Poland in 1921 with the Peace of Riga (later than the rest of Europe, due to the Polish-Soviet War of 1919-1921), Poland felt it had to move its borders as far east as possible to contain the Soviet's territorial ambitions. Polish foresters needed as much timber as they could to produce revenue for the new state (Broda 2006: 52). Unable to organize a wide-scale commercial forestry operation in the early post-war days, Polish State Forestry contracted timber production to the British firm, The Century European Timber Corporation. Between 1916-1924 foreign operators cut over one third of the Białowieża forest, leaving restoration and replanting to the returning Polish foresters (Kossak 2001: 391407). Also, when State Forestry took over from Century, instead of relying solely on the local Belarusian speaking population (deemed unreliable since many had Bolshevik ideology and were members of the Western Belarusian Communist Party), ethnic Polish foresters hired labor from Central Poland (Nikitiuk 2004). Worker colonies sprang up in many pockets of the forest with make-shift housing for the newly arrived men, and Polish Catholic Churches were constructed to serve their spiritual and doctrinal needs. They joined a small minority of Polish Catholics that had lived in the area during the Czarist period.

At the same time that Polish foresters returned to Białowieża, their knowledge was shaped with and against that of field biologists extolling the uniqueness and endangerment of the forest. Moved by the unprecedented damage seen in a post-war visit, Polish botanists, including Wladyslaw Szafer, one of the founders of the IUCN (International Union for the Conservation of Nature) called for Poland's first national park in the area of Białowieża (Szafer 1920). The newly formed state of Poland granted only a small parcel of the forest (45 square $\mathrm{km}$ ) as a strict nature reserve in 1921, while the rest was slated for scientific forest management by the newly formed Polish State Forestry.

Field biologists at the Forest Research Institute, a special organizational unit of State Forestry, quarreled with foresters from the outset (Karpinski 1932). Between cataloguing and studying the unique plant communities in the forest, biologists at the Institute also worked to reconstitute Europe's last wild bison populations using individual bison from zoos across Europe. World War I had led to habitat destruction and hunting, and Europe's last free roaming European bison was shot in Białowieża in 1919 (Krasinski 1994). Zoologists and botanists operating at the Institute carved independence through their science, providing professional supervision of the Białowieża National Park when it was first created in 1932, and guiding the reintroduction of bison in the interwar period (Mahlzahn 2011:12-19).

World War II brought a period of lawlessness and chaos, including further tree felling and poaching in the reserve (Kossak 2001: 459-484). When the Soviets again occupied the forest from September 1939 until June 1941 they utilized their Belarusian connections in the Western Belarusian Communist Party, calling upon local Belarusians to identify Polish foresters so they could be sent to Siberia or to work camps further east. Beginning in 1941, Germans forces protected the forest from logging, largely because of

\footnotetext{
${ }^{5}$ The term Belarusian arose in the nineteenth century as a linguistic category. Belarusian was spoken by the Orthodox and Catholic populations of the region. But as Russia consolidated its grip on Poland after 1864, Catholics became Poles and Orthodox was associated with Belarusians (Woolhiser 2003: 301-305).
} 
Herman Göring's plan to turn the entire Białowieża Forest into his private hunting reserve (Schama 1995: 68-72). Göring's vision never materialized, but Nazis occupied and terrorized the villages for three years. According to many local historians in Białowieża, Göring spent much of the war avoiding the forest for fear of partisan attacks. When the war ended the Yalta agreements split the forest between the Soviet Union (modern day Belarus) and Poland. The result on the Polish side was that ethnic differences were to be 'officially' put aside. Those who identified as Belarusian were given the opportunity to emigrate to the Soviet Union, as only a few of them did (Mironowicz 2007; Wierzbicki 2007; Wysocki 2010).

The relationship between foresters, the Communist Party and locals has not been well documented after the war. Few people wanted to talk about those details, except to say that Belarusians could hold any jobs in Białowieża after World War II. Several historical accounts, however, also show that ethnic Poles continued to hold key administrative positions in Communist Poland (Fleming 2010: 89; Mironowicz 1993:154). My interviews also cast the postwar period as one of continued labor in-migration from Central Poland, a further Polonization of the region.

In interwar Poland and post WWII Poland there were efforts to reforest the landscape using industrial production methods, with rows of spruce and pine monocultures. Half of the logged forest today is a multi-species, multi-storied forest with old growth making up twenty percent of the stands (Niedzialkowski et al. 2012: 2), the other half consists of coniferous plantations. The Forest Research Institute conducted research on the specificity of 'natural forests' and 'natural stands. ${ }^{6}$ But Polish foresters also altered stands to create marketable straight timbers, drained and channeled forest rivers into canals, drying up 'natural' habitats, and they kept the forest floor free of dying and dead timber, all practices that conservationists would object to.

Agitation to expand the 1932 National Park began in the 1980s when both foresters and biologists approached the Polish State about new management rules (Falinski 1992). Five year government plans demanded an infeasible timber yield. Any period of collaboration soon came to an end. In the early 1990s biologists and their activist and conservationist allies had a new international forum for criticizing foresters and forestry, laying the ground for new post-socialist ideas about tourism and forestry.

\section{Building the local}

What changed in Białowieża and Poland in the 1990s was how residents and citizens thought of the nation as 'modern', and thus democratic. With European reunification came new opportunities for Poland to show that it was not only part of Europe, but in some cases superior to it. Successful nature protection became a strategy for highlighting Polish culture. Conservationists who spoke of the forests' European and international importance spurred a campaign asking the nation "who owned the forest?" Celebrity Poles added their names to the campaign, including international journalist Ryszard Kapuscinski, known for his accounts of revolutions in third world countries. Nobel laureate and UC Berkeley Professor Czeslaw Milosz contributed a now-famous article comparing the forest to Krakow's Wawel castle for its importance to national culture (Milosz 1996).

International attention also flourished in the post-socialist period. The BBC, and French and Japanese television, among others, sent film crews and journalists to chronicle primeval natural history. All repeated the phrase "Europe's last primeval forest" at the beginning of their reports. And the forest featured prominently in highly popular English language books, setting the stage for ideas about notions of primeval and European wilderness, such as British historian Simon Schama's treatise Landscape and memory (1995) and American Alan Weisman's The world without us (2007). These books and countless articles and media coverage abroad gave Polish conservationists more fodder to press their case about the importance of the forest at scales beyond the local.

By 2010 Polish conservationists ran with globally circulating ideas about primeval European woodland. They wanted to bring European-wide nature protection laws, such as NATURA 2000, to bear

\footnotetext{
${ }^{6}$ http://www.lasy.gov.pl/zakladki/aktualnosci/puszcza-bialowieska-fakty-i-mity.
} 
on forest management. ${ }^{7}$ They coined their national anti-logging campaign, Ty decydujesz (You decide) inferring that local decisionmaking over whether or not the Park was to be expanded was not appropriate for an issue of national and world heritage. ${ }^{8}$ By 2010 Greenpeace Poland and several other environmental groups sponsored a petition to take the decision out of local hands. They gathered more than 250,000 Polish signatures in support. ${ }^{9}$ By spring 2012 the Polish Environmental Minister promised logging would be scaled back (by 50 percent) and millions of Euros of central funds provided for the local community to develop sustainable community infrastructure such as solar heating, new 'green' certified schools, and sewage treatment plants. ${ }^{10}$

Local people certainly possessed no official rights to the forest. Yet they felt emboldened to speak of how their labor shaped it. Referring to the dead timber lying on the forest floor, locals often repeated to me "I have a right to what's mine." They considered trees they had planted to be an extension of entitlement to the forest. They furthered elaborated that "pseudo experts", meaning the conservationists who had pushed through rules requiring certain amounts of dead timber to lie on the ground, had falsely interpreted the forest ecosystem: foresters simply knew better.

After several assertive attempts by conservationists to expand the National Park over the whole forest area, in 2000 foresters acting in the name of local people convinced politicians to amend the Nature Conservation Act in Parliament. The amendment required acceptance by all affected local and regional authorities before creating new national parks. It effectively halted the creation and expansion of all national parks in Poland following a period in the 1990s when the existing eleven were doubled in number. It was the Białowieża controversy that specifically prompted the amendment.

A rowdy protest catalyzed the amendment, and marked one of the first public assertions that foresters cared about Belarusian identity. ${ }^{11}$ After the Polish Environmental Minister visited Białowieża in 2000, outlining how the area would still become a national park under a "Contract for the Białowieża Forest," foresters organized protests outside their work hours. Locals held signs in Polish and Belarusian naming particular biologists as the cause of their poverty and bearing the slogan "Out EU Judas traitors." They threw eggs at the Environmental Minister. Biologists and their allies found it hard to believe that locals were capable of such organized political action and accused foresters of orchestrating the event.

That watershed protest in 2000 marked an important turn in the region's political ecology. The protest was the first to join the interests of local Poles and Belarusians in opposition to the conservationists' agenda. Polish and Belarusian people were divided by religion (Catholic and Orthodox), took separate holidays, had different religious icons and pictures, and were also divided in their affinity with Russia and the Soviet Union. Back in the1990s conservationists linked the Belarusian character of the area to a "love of communism" as well as supposed cronyism rampant within State Forestry, as evidenced in the gifting of a forest cottage to Prime Minister Wlodzimierz Cimoszewicz in 2001, just as his leftist party, SLD supported the 2000 law on the protection of nature (sic local control).

Conservationists tried to celebrate Belarusian culture in their promotional materials by featuring ornamented cottages and wooden Orthodox churches. Kraina Zubra (Bison Land) was an EU Life + project to cultivate a renewed local identity. It was written by the Mammal Research Institute of the Polish Academy of Sciences, and chose as its symbol some gingerbread house ornaments, in an effort to link protection of bison with regional 'multi-culturalism.' Other conservationists formed groups such as Towarzystwo Ochrona Krajobrazy (Society for Landscape Protection), which supported nature protection with historic landscape, multiple languages, and regional culture.

So if the post-socialist era shook up the region, it also re-territorialized the forest in the name of Belarusian identity. Towns like Hajnowka and Bialystok were centres of this identity in the mid-1990s.

\footnotetext{
${ }^{7}$ http://ec.europa.eu/environment/nature/natura2000/financing/docs/bialowiaza_case_study.pdf

${ }^{8}$ http://www.tydecydujesz.org.

${ }^{9}$ http://www.ekointerwencje.org.pl/index.php?id=243\&lang=pl

${ }^{10}$ http://www.mos.gov.pl/artykul/7_aktualnosci/13388_ministerstwo_srodowiska_na_rzecz_ochrony_puszczy_bialowie skiej_br_ochrona_puszczy_bialowieskiej_wzmocniona_i_zagwarantowana.html

${ }^{11}$ In 2003 the Orthodox population (which is often referred to as Belarusian) made up more than 75\% of the residents of the larger Hajnowka powiat, which included the villages of Bialowieza Forest (Woolhiser 2003: 297).
} 
Several identity activists joined foresters in protest against the park expansion. People told me an expanded national park would destroy the Belarusian minority's chances for democratic development by locking them into a reservation like American"Indians."

Conservationists retorted with resemblances between local attachments to communism and neighboring and corrupt Belarus. They stereotyped Belarusians in Białowieża as a "beaten-down" and "passive" people easily coerced by (Dictator) Lukashenko's logic, and by the forestry sector. In 2013 the monument in front of the Orthodox Church in Białowieza still bore an inscription "to the heroes of socialism." ${ }^{12}$ Conservationists suggested a Belarusian identity that was akin to Homo Sovieticus, deeply rooted in their place history, and representative of their "out of touch" attitude toward a global environmentalist culture. Conservationists often remarked how the streets were still named after local Bolshevik supporters, such as Olga Gabiec. Gabiec was detained in interwar Poland for leading the illegal Communist Party of Western Belarus, whose main goal was to annex Polish lands to the Soviet Union (Latyszonek and Mironowicz 2003).

Few residents of Białowieża crossed to Belarus anymore, and they had lost contact with relatives after the Second World War. But they watched Belarusian television programs and frequently commented on how life in Belarus was more stable than in modern Poland. Some, even those with an ethnic Polish identity, kept tabs on how well managed the Belarusian side of the forest was. The anti-park lobby provided links on its website to a Belarusian television episode, a journalistic exposé on bad Polish forestry. In the report a Belarusian journalist speaking Russian brings a Belarussian forest expert to the Polish side, and there is criticism of the conservationist-inspired law forbidding collection of dead and dying timber in parts of the Polish State Forestry nature reserves. ${ }^{13}$ The report circulated widely and was commented on by residents who opposed the park.

When foresters countered the conservationists' representation of local people as susceptible to authoritarian rule, they inscribed local people as a mild-mannered minority in need of paternal care. ${ }^{14}$ Białowieża carried "democratic" traditions because of foresters' ethos. Foresters evolved a representation of themselves as a trans-historical power that had never lost their independence, even during Poland's socialist era. In fact they saw themselves as instrumental in protecting local minority interests against the 'anti-democratic' conservationists. Foresters too had received international training on topics like community-based forestry, organized for example by the US Forest Service exchanges with Poland in 1998, and with sustainable development support from the Danish Environmental Ministry in 1999 (Antczak 2001).

One senior forestry official explained how democracy and forestry tradition worked in Białowieża by contrasting Poland with neighboring dictatorial Belarus:

In Belarus (on the other side of the transboundary Białowieża Forest) you can have this big national park because the residents of that side of the forest all work in the park, but here in Poland we have residents, ordinary people. Those are people who have rights given to them to settle directly from the Czars. On what principles could we take those rights away from them? We could change that situation but that would be Communistic. There is a proverb in both Polish and Russian, tisze jediesz, dalej budjesz (One can go further if they remain quiet). ${ }^{15}$ Maybe we will find a method of protecting the forest that will quiet everybody. We don't know how to do that, but we can't do this in a spirit of conflict (with the local people). In Communist time you could have created this park, and no one would have disputed it. But now things are different and you must speak up to get what you want.

\footnotetext{
12 The monument was changed in 2014, dropping the word "socialism."

${ }^{13}$ Reportaż o Puszczy Białowieskiej.

https://www.youtube.com/watch?v=0ZJ0Lyq_OMk\&feature=player_embedded\&noredirect=1

${ }^{14}$ For a discussion about Belarusian minority stigmatization in contemporary Poland see Czykwin, E. 2000. Białoruska Mniejszość Narodowa Jako Grupa Stygmatyzowana. Trans Humana, Bialystok.

${ }^{15}$ Transliterated with Polish letters. The forester intended for the proverb to sound Russian and Polish, as he later told me.
} 
Foresters earned the loyalty of local people not because they could provide them with jobs in the postsocialist era, as they had in the communist period when forestry was the employment and resource base in the region, but because they spoke as defenders of the local. In addition, they used the power they acquired through actual appointments to local municipal councils or in tight alliances with those councils to support local people's rights to access the woodland. Moreover, they began to talk about the right to develop local people's private property abutting the national park; land protected by NATURA 2000 laws. The many laborers that were brought in throughout the twentieth century got the opportunity to purchase housing and adjacent meadows that had previously belonged to the state at very reasonable prices. Many of these houses were also in desirable locations, at the edge of the forest in some cases, which made them successful bed and breakfast operations with the tourist boom that followed the post-socialist promotion of Europe's "last primeval forest."

What is striking in this forest conflict is the ability of things European and things Belarusian to command the present and future space of the forest in Poland, while neglecting explicit attention to the ethno-historical and class histories that actually dominated the region. The locally shared history of Białowieża is one where people have not forgotten the past. Poles and Belarusians shared a divided history for much of the twentieth century. Yet it is clear that a new shared identity is emerging where 'local people' reject encroachment by national and global interests that talk about 'their' forest as threatened and which offers 'them' opportunities to develop sustainably. In the process, ethnicity, while present, is subsumed by a shared oppositional experience.

\section{New wealth and allegiances}

There was something teleological about development of post-socialist Europe (Kingston-Mann 1999), especially its rural locations where modernity tried to re-make the backwards countryside into something that resembled a west European standard of living (Cope and Buchowski et al. 2001; Milerius 2008). As I discussed earlier, Eastern Europe has long been projected as the 'underdeveloped' part of Europe, where its elite populations were killed off during WWII and left with unsophisticated villagers, or where there were still too many villages and rural inhabitants. In 1989 Poland for example, 40\% of the population lived in the countryside. The European Union's Common Agricultural Program offered Poland and its farmers only partial subsidies until it could reduce the number of farmers (Dunn 2003).

Białowieża, like most other rural areas of socialist Poland was made up of small peasant farms, often less than 2 or 3 hectares each, many unproductive because of poor soils and crop destruction by wild animals. Ethnic Poles and Belarusians in Białowieża raised pigs, sheep, and cows in the early 1990s. Most plowed potato and rye fields with draft horses and had vegetable gardens to fill their cellars with root crops for the winter. At that time indoor plumbing was a luxury, only seen during visits to urban relatives. Nearly everyone worked in some capacity for State Forestry.

The forest not only supplied full time and seasonal work, but also a direct resource for household consumption. Foresters told local people to refrain from logging, poaching, or grazing cattle in the woodland (which had been legal until the 1970s). But according to the people I interviewed, they often turned a blind eye to these practices. Only since about 2005, when the tourist boom began, have they largely stopped going to the forest for work and food and fuel. 'Forest access' is still a talking point, but with the explosion of the tourist industry, and local peoples' rising incomes, few still visit the forest even to collect mushrooms and berries. They say they are too busy with their businesses to find the time (Niedzialkowski et al. 2014).

In the 1990s backers such as the World Bank's GEF (Global Environmental Fund) and the Danish Environmental Minister provided financing and expertise to State Forestry, the National Park and the local councils to support a future that was not based on logging. ${ }^{16}$ Beginning in 1998 WWF worked to build better tourist infrastructure encouraging households to convert their homes into mixed agro-tourist

\footnotetext{
${ }^{16}$ Report \#10298. "Poland Forest Biodiversity Project." January 31, 1992. World Bank GEF Project Document.
} 
operations. $^{17}$ Many development efforts counted on a local entrepreneurial spirit to overcome obstacles to nature protection.

The models put forth celebrated and showcased the tiny farmsteads at the edge of the great forest where people were supposed to retain their communitarian traditions while also intensifying their individualistic and entrepreneurial initiative (Radecki 1996). Training was offered on running a small business and meeting health codes for home stays. Economic growth and tourist growth spurred by early international attention on the region yielded contradictory results. Many residents gave up farming. With better marketing and food availability, it was cheaper to purchase staples like milk and meat from the store than to grow their own. Residents frequented foreign-owned hypermarkets in nearby Hajnowka, such as the German-owned Kaufland and the Portuguese-owned Biedronka, where they also bought food for their bed and breakfast clients. They remodeled their small wooden cottages into towering three- and four-story tourist accommodation. Three large hotel complexes also vied for opportunities to build in the most accessible and attractive locations, and in their decorative motifs conjured a non-specific peasant past linked to royal dramas. The Best Western Hotel Żubrówka, Białowieża featured the nightclub The Czar's Boudoir, and another hotel called Soplicowo was named after the manor house in the epic poem Pan Tadeusz by Polish bard Adam Mickiewicz.

The booming tourist economy triggered a politically empowered local community. Instead of continuing to work for State Forestry, many households developed their own businesses. Nearby town residents were now commuting to Białowieża to work in the big hotels. The Białowieża Forestry district, an area of some 2,500 inhabitants (many of them elderly and retired) employed 150 full time employees in 2011 and hired approximately 50 seasonal laborers as wood cutters. By contrast the tourist industry employed around 500 people, working in the hotels, as tourist operators, and many who own their own bed and breakfasts and other businesses, including restaurants. Local people who became successful business owners saw their interests advanced by state foresters rather than by conservationists. The strict protection model was linked to keeping the villages of Białowieża 'village-like', and was seen as 'outsiders' coming in and telling them what to do. Foresters asserted their model for successful economic development as one that supported local rights, front and center (Bobiec 2004).

Even as residents achieved a high level of development, as seen in the visible markers of remodeled homes and new cars (Figure 2), local people played up the notion that they relied upon the forest for their subsistence, as if they were trapped in a former development stage by conservationists. In 2013 a BBC television program featured one local man who reported that local people who were freezing cold in winter could go ask the conservationists why they didn't have fuel for heating. In fact, most local households had already converted to highly efficient biofuel furnaces, funded by sustainable development funds from the NFOSIGW (The National Fund for Environmental Protection and Water Management), and powered by sawdust, wood chips and other forest waste that could be obtained easily from the large commercial pine plantations surrounding the Białowieża Forest (Niedzialkowski et al. 2014). ${ }^{18}$

The dramatic social and economic changes to the region sometimes registered in a lament on the part of local people, and also in a strict guarding of their new privilege. Even as they had considerably more material wellbeing, jealousy was rampant between neighbors. From my interviews, people remembered a time of collective solidarity when they all went to plant trees together in the forest. Work in the forest had been a focal point for community unity.

In turn, foresters adopted the language of the local, and downplayed their history of ever working against Belarusian identity. While clearly continuing to be part of a much larger nationwide organization, state foresters started to blame national and international interests for usurping local democracy. Foresters adopted a position of serving the local, and of local traditions. The 'local' became a stand-in for anyone who was not a conservationist or scientist. Locals also spoke of the legitimacy of the forester, as the ruler and specialist on all matters pertaining to the forest.

${ }^{17}$ Communist-era tourist infrastructure was already in place in 1989, but increased to an unprecedented scale in the 2000s.

${ }^{18}$ http://news.bbc.co.uk/2/hi/programmes/fast_track/9714333.stm 


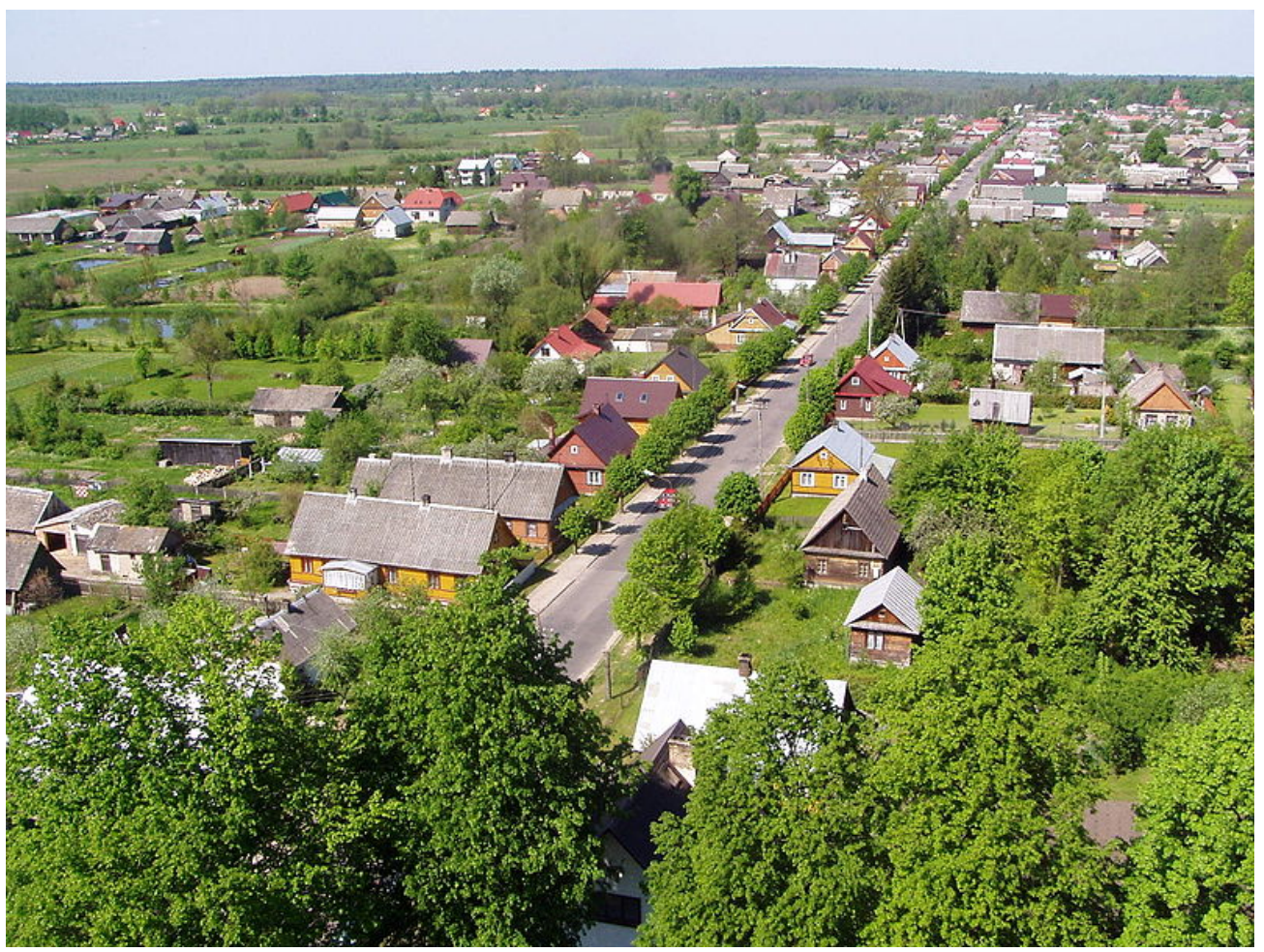

Figure 2: Białowieża village, 2005. Source: Wikimedia commons, GNU Free Documentation License.

One manufacturer who makes ceramic bison for tourists told me; "the forester is like the auroch (the ancient progenitor of the domestic cow). He keeps the canopy open for new growth." A seasonally employed woodcutter, now working as an independent contractor, said:

The forester is the boss and specialist. He should be telling us all what to do with the forest, not some environmentalist who doesn't have a clue.

The yearning for a rural order, with the forester at the top, symbolized a hope that foresters, given the right amount of power and free from conservationists' meddling, could revive a golden age of village unity with continued local possibilities to develop their estates free of restrictions imposed at the national and EU level.

\section{Conclusion: reversing orders}

Conservationists in this case adopted the language of the Polish nation as a modern one, superior to, but also looking after the concerns of Europe. But foresters chose an underdog position, via the Belarusian identity of the local, to retain their authority and position in their downsized but no less powerful state operation. This is not to say that local knowledge of the forest and a foresters' knowledge were identical, nor that state foresters were no longer acting as agents of the state after 1989. Rather, post-socialism confused issues of the nation, the periphery, and most importantly, the identity of the Białowieża forest. A capitalist form of nature tourism and the implementation of transnational conservationist concepts and programs produced unexpected constellations shaped by specific context and the histories, politics, and ecologies of place. Poland is not alone; there are shifting territorialities and allegiances not just in the wake of globalization but also in the wake of post-socialism, where nations such as Belarus and Ukraine continue to reinvent dreams of reviving Soviet autocratic norms in daily life. 
As for local knowledge, locals were not necessarily looking at the trees in terms of scientific forestry, as a schedule of areas to be felled or in terms of board feet of saleable timber, when they saw the forest or even remembered their days laboring in it. But they did see a working commercial forest that would maximize a profit from its timber. The local point of view was of a forest that needed the forester and his hierarchy of values, including his ecological interpretation of the woodland. Local people did respect and commit to State Forestry, with its superior forest knowledge. When Poles and Belarusians were divided in the interwar period by political support for communism, and again during WWII in collaborations with occupying armies and partisans, it would be surprising to find the same level of unity in the population regarding the forester. A lack of unity was still in place after the War, when Belarusians were still not on an equal political footing with Poles, and even when Poles and Belarusians grazed cattle in the forest up until the 1970s.

Support for the forester and his model of forestry was possible because local peoples' values altered over time. Latterly, they entered the forest less often, and like most entrepreneurial people they grew concerned about how to increase their profits, rather than how to subsist from, or nurture, the woods. The forest came to symbolize development possibilities, and foresters also supported this. As a primeval icon of European nature, the Białowieża Forest has become linked to ancestral ideas of Europe and to European democracy (Herzfeld 1987). In the era where Poland 'rejoined' Europe through European Union membership in 2004, its forested border with Europe's last dictatorship in Belarus hosted a local movement. Forestry, and Belarus, evoked memories of full employment under communism. In a very real way for locals and conservationists, there was less condemnation of the communist past. In the post-socialist situation the idea of communism becomes a flexible tool to reimagine circumstances in the present: what it means to be modern is precisely to neutralize the past (Hobsbawm and Ranger 1983). Hence, private ownership in the forest has also received some discussion at the legislative level. Polish state foresters, in these altered circumstances, have localized their policies and identities - but only because global opportunities and development projects have also 'produced' the idea of the local.

We would expect that environmental politics in the region would support a re-territorialized forest, given the global and pan-European conservationist and preservationist agenda. But this is not the case. It is in fact foresters who have downplayed the importance of the Białowieża Forest for the nation. Polish foresters have conceptualized their 'sustainable' form of forestry as transnational, but not really international, believing that their connection to Belarus is bound up in a responsible attitude toward forests and people; that forests need foresters, and so do forest communities. Foresters on the Polish side of the border must identify with the multi-cultural 'local.' By doing so they seem to be transcending cultural differences that once divided the region, and are entering into a new era of democracy and sustainable development.

The imagined past of everyone working together productively and peacefully in the forest works as a kind of nostalgia that unites locals in opposition to conservationists' plans to expand the national park, which would further control the ecological management of the forest, ban logging, and therefore end state forestry in the Białowieża Forest. This is the reality of the post-socialist political ecology of the Białowieża Forest.

\section{Bibliography}

Anderson, D. and R. Grove (eds.). 1987. Conservation in Africa: people, policies and practice. Cambridge: Cambridge University Press.

Andrews, M. 2002. Mexican forest history: ideologies of state building and resource use. Journal of Sustainable Forestry. 15:1:19-30.

Andrews, M. 2009. Unlikely alliances: encounters between state science, nature spirits, and indigenous industrial forestry in Mexico 1926-2008. Current Anthropology. 50(1):75-101.

Antczak, A. 2001. Background to management guidelines for Białowieża forest. The Białowieża Forest DANCEE Project. 
Appadurai, A. 2003 (1996). Sovereignty without territoriality: notes for a postnational geography. In Low S.M. and D. Lawrence-Zúñiga (eds.) The anthropology of space and place. New York: WileyBlackwell. Pp 337-350.

Beinart, W. and P. Coates. 1995. Environment and history: the taming of nature in the USA and South Africa. New York: Routledge.

Berdahl, D. 2010. On the social life of postsocialism: memory, consumption, Germany. Indianapolis: Indiana University Press.

Blavascunas, E.L. 2007. Border trouble: constituting and crossing borders in the Białowieża Primeval Forest. In M. Darley and P. Bauer (eds.). Borders and boundaries in the European Union: crossing and resisting strategies. Prague: Centre Français de Recherche en Sciences Sociales.

Blavascunas, E.L. 2008. The peasant and communist past in the making of an ecological region: Podlasie, Poland. PhD dissertation. University of California, Santa Cruz.

Blicharska, M. and P. Angelstom. 2010. Conservation at risk: conflict analysis in the Białowieża Forest, a biodiversity hotspot. International Journal of Biodiversity Science, Ecosystem Service and Management. 6(1-2): 68-94.

Bobiec, A. 2004. Chronimy czy wycinamy: Mija 80 lat od powstania Lasow Panstwowych. Tygodnik Powszechny. Nr. 26. 27.

Boym, S. 2001. The future of nostalgia. Basic Books: New York.

Braun, B. 2002. The intemperate rainforest: nature, culture and power on Canada's West Coast. Minneapolis: The University of Minnesota Press.

Broda, J. 2006. Lesne dziedziectwo po okresie zaborow I powjenne uwarunkowania. In Szujecki A. (ed.) Z Dziejow Lasow Panstwowych I Lesnictwa Polskiego 1924-2004. Dyrekcji Generalnej Lasow Panstowych. Warsaw. 1: 29-97.

Brosius, P., A. Tsing and C. Zerner (eds.). 2005. Communities and conservation: histories and politics of community-based natural resource management. Walnut Creek, CA: Alta Mira.

Buchowski, M., E. Conte and C. Nagengast. 2001. Poland beyond Communism: transition in critical perspective. Memphis: University of Memphis.

Carr, D. and K. Halvorsen. 2001. An evaluation of three democratic community-based approaches to citizen participation: surveys, conversations with community groups, and community dinners. Society and Natural Resources. 14:107-126.

Cellarius, B. 2004. In the land of Orpheus: rural livelihoods and nature conservation in postsocialist Bulgaria. Madison: University of Wisconsin Press.

Cope, B. and N. Milerius (eds.). 2008. Becoming urban? Investigating the P-S (post-Socialist/post Soros) landscape. Minsk: European Humanities University.

Crandell, G. 1993. Nature pictorialized: the view in landscape history. Baltimore: John Hopkins University Press.

Dawson, J. 1996. Econationalism: anti-nuclear activism and national identity in Russia, Lithuania and Ukraine. Durham: Duke University Press.

Davies, N. 2005. God's playground: 1795 to the present. New York: Columbia University Press.

Dunn, E.C. 2003. Trojan pig: paradoxes of food safety regulation. Environment and Planning A 35(8): $1493-1511$.

Dunn, E.C. 2004. Privatizing Poland: baby food, big business and the remaking of labor. Ithaca: Cornell University Press.

Falinski, J. 1992. Bialowieski Park Narodowy (1921-1991) - proba 70 lat. Chronmy Przyrode Ojczysta 48(3): 5-15.

Fleming, M. 2010. Communism, nationalism, and ethnicity in Poland: 1944-50. New York: Routledge.

Franklin, S. 2002. Białowieża Forest, Poland: representation, myth, and the politics of dispossession. Environment and Planning A 34(8): 1459-1485. 
Gellner, E. 1988. Malinowski between two worlds: the Polish roots of an anthropological tradition. Cambridge: Cambridge University Press.

Gezon, L. 2006. Global visions, local landscapes: a political ecology of conservation, conflict and control in Northern Madagascar. Lanham, MD: Altamira Press.

Gille, Z. 1997. Two pairs of women's boots for a hectare of land: nature and the construction of the environmental problem in state socialism. Capitalism, Nature and Socialism 8(4):1-22.

Gille, Z. 2000. Legacy of waste or wasted legacy? The end of industrial ecology in post-socialist Hungary. Environmental Politics 9(1): 203-31.

Greenough, P. and A. Tsing (eds.) 2003. Nature in the global South: environmental projects in South and Southeast Asia. Durham, NC: Duke University Press.

Grodzinska-Jurczak, M. and J. Cent. 2011. Expansion of nature conservation areas: problems with Natura 2000 implementation in Poland. Environmental Management 47(1): 11-27.

Hackel, J. 1999. Community conservation and the future of Africa's wildlife. Conservation Biology 13(4): 726-734.

Hann, C. et al. 2007. Anthropology's multiple temporalities and its future in Central and Eastern Europe: a debate. Max Planck Institute for Social Anthropology Working Papers 90. Berlin: Max Plank Institute.

Harrison, R.P. 1992. Forests: the shadow of civilization. Chicago: University of Chicago Press.

Heatherington, T. 2010. Wild Sardinia: indigeneity and the global dreamtimes of environmentalism. Seattle: University of Washington Press.

Hetherington, K. 2011. Guerilla auditors: the politics of transparency in neoliberal Paraguay. Chapel Hill: Duke University Press.

Hecht, S. and A. Cockburn. 1990. The fate of the forest: developers, destroyers and defenders of the Amazon. Chicago: University of Chicago Press.

Hecter, M. 1999. Internal colonialism: the Celtic fringe in British national development. New Brunswick: Transaction.

Herzfeld, M. 1987. Anthropology through the looking glass: critical ethnography in the margins of Europe. Cambridge: Cambridge University Press.

Herzfeld, M. 2004. The body impolitic: artisans and artifice in the global hierarchy of value. Chicago: University of Chicago Press.

Hicks, B. 1996. Environmental politics in Poland: a social movement between regime and opposition. New York: Columbia University Press.

Hobsbawm, E. and T. Ranger. 1983. The invention of tradition. Cambridge: Cambridge University Press.

Igoe, J. 2004. Conservation and globalization: a study of national parks and indigenous communities from East Africa to South Dakota. Riverside, CA: Wadsworth.

Karcow, G. 1903. Bielowieszskaja Puszcza. St. Petersburg.

Karpinski, J. 1932. Sprawozdanie kierownika Park Narodowego w Białowieżay za rok 1932. Ochrona Przyroda 12: 156-157.

Kieniewicz, S. 1969. The emancipation of the Polish peasantry. Chicago: University of Chicago Press.

Kingston-Mann, E. 1999. In search of the true West: culture, economics, and problems of Russian Development. Princeton: Princeton University Press.

Kosek, J. 2006. Understories: the political life of forests in Northern New Mexico. Chapel Hill, NC: Duke University Press.

Kossak, S. 2001. The saga of the Białowieża Forest. Bialystok: Poland. Bialydruk.

Krasinki, Z. 1994. Restitution of the European bison in the Białowieża Reserve in the years 1929-1952. Parki Narodowe i Rezerwaty Przyrody 4: 2-23.

Latyszonek, O. and E. Mironowicz. 2003. Historia Bialorusi, Zwiazek Bialoruski w RP. Katedra Kultury Bialoruskiej. Bialystok University. 
Leonard, P. and D. Kaneff. 2002. Post-socialist peasant? Rural and urban constructions of identity in Eastern Europe, East Asia and the former Soviet Union. New York: Palgrave.

Lowe, C. 2006. Wild profusion: biodiversity conservation in an Indonesian archipelago. Princeton: Princeton University Press.

Lowood, H. 1990. The calculating forester: quantification, cameral science, and the emergence of scientific forestry management in Germany. In Frängsmyr T., J.L. Heilbron and R.E. Rider (eds.) The quantifying spirit in the Eighteenth century. Berkeley: University of California Press.

Mahlzahn, E. 2011. Activity report of the Biatowieza Department of the Forest Research Institute. Sekocin Stary: Institute Badawczy Lesnictwa.

Manser, R. 1993. Failed transitions: the Eastern European economy and environment since the fall of Communism. New York: New Press.

MacKenzie, J. 1990. Imperialism and the natural world. Manchester: Manchester University Press.

Menzies, N. 2007. Our forest, your ecosystem, their timber: communities, conservation, and the state in community-based forest management. New York: Columbia University Press.

Milosz, C. 1996. Rozebrać Wawel na cegły? Tygodnik Powszechny. 18 February.

Mironowicz, E. 1993. Bialorusini w Polsce. Warsaw.

Mironowicz, E. 2007. Białorus. Wydawnictwo Trio: Warsaw.

Nagengast, C.1991. Reluctant socialists, rural entrepreneurs: class, culture, and the Polish State. Boulder: Westview.

Neumann, R. 1998. Imposing wilderness: struggles over livelihood and nature preservation in Africa. Berkeley: University of California Press.

Niedzialkowski, K., J. Paavola, and B. Jędrzejewska. 2012. Participation and protected areas governance: the impact of changing influence of local authorities on the conservation of the Białowieża Primeval Forest, Poland. Ecology and Society 17 (1): 2.

Niedzialkowski, K., M. Blicharska, G. Mikusiński and B. Jędrzejewska. 2014. Why is it difficult to enlarge a protected area? Ecosystem services perspective on the conflict around the extension of the Białowieża National Park in Poland. Land Use Policy. 38: 314-329.

Nikitiuk, B. 2004. Z dziejów Hajnówki i jej okolic (1915-1939). Hajnówka: Starostwo Powiatowe w Hajnówce.

Oelschlaeger, M. 1991. The idea of wilderness: from prehistory to the age of ecology. New Haven: Yale University Press.

Peluso, N. 1992. Rich forests, poor people: resource control and resistance in Java. Berkeley: University of California Press.

Peluso, N. 1993. Coercing conservation? The politics of state resource control. Global Environmental Change. 3(2): 199-217.

Petryna, A. 2002. Life exposed: biological citizens after Chernobyl. Princeton: Princeton University Press.

Radecki, A. 1996. Agriculture in the region of Biatowieża Primeval Forest. Fundacja Rozwoj SGGW. Warsaw.

Rajan, S. R. 2006. Modernizing nature: forestry and imperial eco-development 1800-1950. New York: Oxford University Press.

Raffles, H. 2002. In Amazonia. Princeton: Princeton University Press.

Ranger, T.O. 1999. Voices from the rocks: nature, culture \& history in the Matopos Hills of Zimbabwe. Bloomington: Indiana University Press.

Samojlik, T. 2005. Conservation and hunting in the time of kings. Białowieża: Mammal Research Institute.

Schwartz, K. 2006. Nature and national identity after Communism: globalizing the ethnoscape. Pittsburgh: University of Pittsburgh Press.

Scott, J. 1998. Seeing like a state: how certain schemes to improve the human condition have failed. New Haven: Yale University Press. 
Schama, S. 1995. Landscape and memory. New York: Knopf.

Sivaramakrishnan, K. 1999. Modern forests: statemaking and environmental change in colonial Eastern India. Stanford: Stanford University Press.

Sivaramakrishnan, K. and A. Agrawal (eds.) 2003. Regional modernities: the cultural politics of development in India. Palo Alto: Stanford University Press.

Staddon, C. 2009. Towards a critical political ecology of human-forest interactions in Bulgaria. Transactions of the Institute of British Geographers 34 (2): 161-176.

Stahl, J. 2010. Rent from the land: a political ecology of postsocialist rural transformation. London: Anthem Press.

Sunseri, T. 2012. Exploiting the Urwald: German post-colonial forestry in Poland and Central Africa, 1900-1960. Past and Present 214: 305-342.

Szafer, W. 1920. Plan utworzenia rezerwatu lesnego w Puszczy Bialowieskiej. Chronmy Przyrody Ojczysta 6.

Taussig, M. 1980. The devil and commodity fetishism in South America. Chapel Hill: University of North Carolina Press.

Tsing A. 1999. Becoming a tribal elder, and other green development fantasies. In Li, T. (ed.) Transforming the Indonesian uplands. London: Routledge.

Tsing, A. 2004. Friction: an ethnography of global connection. Princeton: Princeton University Press.

Tsing, A. and C. Zerner. 2000. People, plants and justice: the politics of nature conservation. New York: Columbia University Press.

Vera, F. 2000. Grazing ecology and forest history. Wallingford: CABI Publishers.

Weisman, A. 2007. The world without us. New York: St. Martin's Thomas Dunne Books.

Wierzbicki, M. 2007. Polacy i Bialorusini w zaborze wieckim. Stosunki Polsko-Bialoruskie na ziemiach Pótnocno-Wschodnich II RP pod Okupacja Sowiecka 1939-1941. Warszawa: Stowarzyszenie Kulturalne Fronda.

Wilson, E.O. 2012. The social conquest of Earth. New York: Norton.

Wolff, L. 1994. Inventing Eastern Europe: the map of civilization on the mind of the enlightenment. Stanford: Stanford University Press.

Woolhiser, C. 2003. Constructing national identities in the Polish-Belarusian borderlands. Ab Imperio 1: 293-346.

Wysocki, A. 2010. Belarusians and Belarusianness in the face of Soviet people and Sovietization in Western Belarus in the years 1939-1941 in the memoirs of Polish people. Annus Albaruthenicus 10. Krynki, Poland: Villa Sokrates.

Yurchak, A. 2005. Everything was forever, until it was no more: the last Soviet generation. Princeton: Princeton University Press. 